\title{
Interpreters of the past and of the present: the art of historians of education and archivists
}

\section{Interpretes do passado e do presente: a arte de historiadores da educação e arquivistas}

\author{
Diana Gonçalves Vidal ${ }^{1}$ \\ Orcid: http://orcid.org/0000-0002-7592-0448 \\ Universidade de São Paulo, São Paulo, Brasil, dvidal@usp.br \\ José Cláudio Sooma Silva² \\ Orcid: https://orcid.org/0000-0003-3647-8703 \\ Universidade Federal do Rio de Janeiro, Rio de Janeiro, Brasil, \\ claudiosooma@gmail.com \\ Received on 18/05/2020 - Approved on 18/05/2020
}

\begin{abstract}
:
Interpreting former times is not the sole province of historians. It is a constitutive act of the arts performed by writers, exhibition curators, docufilm directors, film writers and scenographers, re-enactors. But not only, it is also an element of the practice of historians of education and archivists, of people who throughout their lives collect records, of the exercise of patrimonial education on the part of teachers and of the organizers of school museums. Framing the discussion on the craft of historians of education and archivists, we structured the article into two parts. The first part focuses on the historiographical narrative in education, taking an example from the Brazilian history of education. The second part deals with some of the dimensions present in the acts of archiving, focusing on particularly the materiality of the documents.
\end{abstract}

Keywords: Historiography, History of Education, Archives, Materiality

\section{Resumo:}

Conferir sentido aos tempos pretéritos não é uma tarefa exclusiva de historiadores. É um ato constitutivo das artes de escritores, curadores de exposições, diretores de documentários, roteiristas e cenógrafos, reencenadores. Mas não apenas, é também um elemento integrante da prática de historiadores da educação e arquivistas, de sujeitos que ao longo da vida colecionam registros, do exercício da educação patrimonial por parte de professores e de organizadores de museus escolares. Circunscrevendo a discussão ao ofício de historiadores da educação e arquivistas, estruturamos o artigo em duas partes. A primeira parte se concentra na narrativa historiográfica em educação, tomando um exemplo da história brasileira da educação. A segunda trata de algumas das dimensões presentes nos atos de arquivamento, concentrando-se particularmente na materialidade dos documentos.

Palavras-chave: Historiografia, História da educação, Arquivos, Materialidade. 


\section{Introduction}

Caught in the urgency of giving answers to the challenges of the present, subjects not always pay attention to the dimensions of the past that constitute their practice, or question themselves about the regimes of truth (Foucault, 2012) that produce the present day in its difference from/contiguity to yesterday. Interpreting former times is not the sole province of historians. It is a constitutive act of the arts performed by writers, exhibition curators, docufilm directors, film writers and scenographers, re-enactors. But not only, it is also an element of the practice of historians of education and archivists, of people who throughout their lives collect records, of the exercise of patrimonial education on the part of teachers and of the organizers of school museums.

All those strands have in common, however, the fact of being socio-historical constructions constrained by reasons belonging to the present days in which they emerged and configured within the field of possibilities offered by them. As layers, they sediment various presents and feed different interpretations about the past, interpretations also dated and resulting from negotiations between concurrent representations about today and yesterday, constituted by the competing groups in society throughout history.

Framing the discussion on the craft of historians of education and archivists, we structured the article into two parts. The first one focuses on the historiographical narrative in education in Brazil and highlights the shift, operated within the field, particularly since the mid-1980s, when researchers came closer to archives findings. The second part investigates some of the dimensions existent in acts of archiving, conceived also as a way of giving meaning to the past, throughout the narrative archivists produce when organizing collections.

\section{History of Education and the places of enunciation: adjusting the reflective lens}

"What do historians really fabricate when they 'make history'? What are they 'working on'? What do they produce?" The three questions put forward by Michel de Certeau in the opening of his historiographical investigation constitute warnings to those who intend to take on the challenge of employing the written word as a tool (1988, p. 56). By emphasizing the production and construction, his questions stresses the contingencies of today in the arts of fabricating meanings to yesterday.

Highlight such interferences and inventiveness of the present means above all to pay attention to the tensions and disputes that characterize those efforts. The accents conferred, the moments subsumed, the representations constituted during the construction of documental collections and the articulation of the narrative must be perceived, beyond author inclinations, as integral parts of a historiographical operation elaborated with the aim of establishing regimes of truth (Foucault, 2012). From this point follows the blurring of the distinction between history and historiography, since every research in history must be examined in its historiographical meaning, that is: a "practice (a discipline), its result (a discourse), and the relation of the two in the form of a 'production"' (De Certeau, 1988, p. 21). 
What could be at first sight a minor issue (replacing history by historiography) constitutes in fact a theoretical standing that scrutinizes the work of historians not as "reflections of reality but representations of it" (Burke, 2001, p. 12). Something that, related to the certainty that "We can never form more than an approximate idea of how tales were told in the past" (Darnton, 1999, p. 261), contributes to make us approach any production in history in terms of the historicity that demarcates and permeates the exercises in archiving, the documental collections constructed, the field of research, and the very fabric of the narrative.

Underlining some of the features of the practices of historians, and emphasizing the interweaving of history and history of education constitute thereby an invitation to remain alert to the disputes, emotions, tensions and negotiations that have been (and have remained) involved in the (unending) exercise of conferring meanings to the educational past. Something that contributes both to make us think about some of the (mis)routings that have brought us to the present and to raise other possibilities related to that which we may perhaps become.

Thus, discussing aspects related to the places of enunciation of the historian consists in one of the challenges that must be faced by those who intend to delve into the exercise of the production of knowledge in the history of education. After all, both the potentialities and the highlights of the limits and the silences of an analysis speak of the options, selections, criteria and angles that have been privileged by one historiographical operation or another (De Certeau, 1988). Along these lines, to bring to the foreground the adjustments and angulation of the reflective lens employed, much more than a metaphorical movement, signals to the concern with making explicit the arsenal of theoretical-methodological precautions mobilized with the objective of constructing interpretations for times gone by.

In the Brazilian case, this debate emerged in the mid-1980s and coincided with the political revival after 20 years of military dictatorship. The return of the country to democratic life placed the challenge of reviewing the past and understanding the forces that allowed the construction of certain views about education and its history. The still fresh experience of the regime of exception challenged the analyses committed to continuity, and favored a repertoire based on ruptures. In this scenario, Michel Foucault (1975) assumed both for the field of history and for the arena of history of education the role of an unavoidable reference. The new scene also brought with it a definite interest in the agency of the people, and a commitment to the trajectory of subjects, not only of the great pedagogues of yesterday, but also of common women and men conceived after social markers of gender, race/ethnicity, and social class.

In that manner, the two main historiographical traditions in education found themselves challenged. At the same time, the interest for new sources and archives was awakened. The legislation that had hitherto been the alma mater of the researches had to live alongside the most varied documents, from judicial sources to photos, paintings, films, literary works and other historical records that engender varied possibilities to investigate the traces of everyday school life. The intrinsic relation between history and philosophy of education was also disturbed. As argued by Diana Vidal and Marília Carvalho (2001), far from characterizing a "rupture, it initiated a decisive preoccupation with the source of the writing of a history of and about Brazilian education" (p. 206, free translation), a movement that was largely due to the new and proficuous dialogues between educational historiography and history. 
Such approximations and dialogues with the field of history changed in different ways the manner of circumscribing and carrying out the analyses undertaken. They contributed to a providential "explosion of themes and objects of research in history of education in the 1990s" (Catani; Faria Filho, 2002, p. 126, free translation). After all, problematizing the emphases, intentionalities and recognitions that permeate each and every historiographical operation concurred to bring out multiple possibilities of investigating educational situations in Brazil. Something that signaled both to a "revival of themes" and to the casting of "new looks" upon other issues that had already been investigated by educational historiography.

Such revival and new outlook contributed decisively to lay bare certain "historiographical myths" regarding the educational past (Schueler, 2002). Within the angles explored in this article, we chose to exemplify only one of them. It refers to the thesis that delving into the public education of the $19^{\text {th }}$ century would mean solely to talk about the social times experienced by the "White elites".

Starting from a view based on the legislation that prevented schools from taking slaves as pupil, the conception was built that Blacks did not attend schools during the $19^{\text {th }}$ century. At this point, we observe a direct (and mistaken) association between being Black and being a slave, without reflecting on the other statutes that a black man or woman could have in Brazilian society at the time, such as being free, having been freed or emancipated. It is also important to emphasize that, even focusing the analysis on the legislation, according to the 1824 Constitution, Blacks were not forbidden to attend public classrooms, the impediment referred to slaves via the condition of being non-citizens (see articles 6 and 179 of Brazil's first Constitution of 25 March 1824).

However, even taking this legal prohibition into account, different studies have indicated the presence of Blacks (freed and slaves) in school times and places throughout the $19^{\text {th }}$ century in different regions of Brazil (Silva, 2000; Schueller, 2002; Vidal, 2008, Moraes, 2015, among others). On the other hand, when we turn our attention to the disseminated education practices, it has been possible to locate the presence of slaves (including children) in systems of learning of different crafts, which often included reading, writing and counting (Silva, 2007). These new interpretations of the history of education were driven by a decisive revisionism of Brazilian slavery emerging in the seedbeds of history.

A whole field of research has emerged making use of judicial and administrative documentation, in which an attempt has been made to underline the agency of slaves and to examine closely their strategies to survive and overcome difficulties. A new and fresh interest for archives documents opened up researchers to the maneuvers employed to escape the relations of domination imposed by the slave society, either violent ones, such as murder and suicide, or subtle ones, such as gossip and slander (Slenes, 1999; Chalhoub, 1990; Schwarcz, 1987, among others). This movement was not restricted to Brazil, it emerged also in American (Genovese, 1974) and Caribbean historiography (Scott, 1985). The agency of slave men, women and children of both genders appeared as a legitimate object of investigation, giving new meanings to the life experience of those subjects.

However, if delve into archives allowed new interpretations, it is not neglectable that the tools that engender different possibilities to scrutinize the traces of yesterday in the documentation kept in research institutions turn out to be of paramount importance. We refer here to lists, tables, codes, organizations, collections, inventories, seriations, typologies, databases, source listings et cetera, 
which are produced routinely by archivists and presented to historians and historians of education.

Indeed, it seems difficult, if not impossible, to imagine navigating through hundreds of kilometers of documents kept in a research institution without such tools. Likewise, just as historians fabricate history and, in this operation, "Far from accepting "data", this gesture forms them" (De Certeau, 1988, p. 73), archivists also fabricate the past when organizing collections and writing research instruments. None of these tasks are neutral, rather they are operations within an academic field, the archivology.

\section{The acts of archiving and the materiality of documents}

Arlette Farge (1989) describes magisterially the pleasure of accessing documents in an archive. The gestures, the excitement of the discovery, the pitfalls and temptations experienced by researchers and the power of words. She alerts that the archive is not the remnant of the past as it seems to be. Wills of memory and fortune enabled documents to survive. In emphasizing these dimensions, she underlines that both the selections and silences as well as the surprises and unforeseen events are intrinsically present in the archives and, more importantly, produce substantial interferences in the moments that precede and accompany the elaboration of any study. In addition, Michel de Certeau (1988) reminds us that the organization of collections is the result of the archivists endeavor, guided by the rules of a discipline, archivology. That means that not only the documents, but also the process of archiving should be interrogated by researchers.

According to Le Goff (1984, p. 38), it was only with the French Revolution that the national archives appeared, opening "a new phase, that of the public availability of documents in national memory". The dissemination of public archives in the 19th century led to the creation of institutions specialized in preparing specialists, such as the Ecole des Chartes (Paris, 1821), the Institut für Österreichische Geschichtsdforschung (Vienna, 1854) and Scuola de Paleografia e Diplomatica (Florence, 1857).

Born in this way, in the midst of 19th century discussions about the sciences and with the objective of ensuring the conservation of information in the public sphere, archivology has perceived, from its beginnings, the document in the political, institutional and legal dimension, by the positive value of evidence or monumentally of the great characters and events. Much has happened since then, but archivology remained faithful to five main principles: of Provenance; of Respect for the Original Order; of Organicity; of Oneness; and of Indivisibility or integrity.

Favoring them presupposes identify the history behind the data or the history institutions and subjects want to tell when collecting documents. The work ranges from regularities to differences in a constant pendular movement. While the regularities allow the identification of the structure and the arrangement of documental series and, therefore, operate as a contingency of the act of archiving, it is the differences that raise the questions about the changes undergone by the archives during its constitution, such as for example changes in organograms in the case of institutional archives, and changes in the life trajectories in personal archives. 
Both pendular movements bring the possibility of problematizing the documentation, and open up the documental corpus to interpretations, promoting a reflection about the dynamics of personal or institutional practice of archiving.

In addition, as Pierre Nora (1993) alerts, the process of keeping is always the result of a selection, guided by operative criteria at the moment when it is done, and produces an effect of sense. Thus, the act of archiving of a documental corpus reveals the criteria that gave support to it and foster the monumentalization of the institution or subject to which the archive belonged or still belong. Both practices are not inert, and promote the unveiling of the conscious and unconscious drives that created the conditions of their emergence.

However, by setting up a structure to an archive, by arranging series, subseries, typologies or collections the archivist not merely retraces the archive history, he/she actively produces a narrative and engenders senses to the collection. Described individually, the document takes on a new meaning when associated to the others that comprise a series. The interpretation it receives varies according to its position in the documental whole that constitutes the archive and depends both on principles of archivology and on the understanding that the designers of the archive had of it. To be sure, with current day informatics resources, the same document can be virtually associated to different series with reciprocal references. But the physical place it occupies in the archive reveals a kind of understanding of its provenance or function on the part of the person who archived it. Therefore, examining the criteria of archiving can reveal both the principles of a theory (the archivology) and the result of a practice (the archiving).

Apart from the content of a document or a collection, their materiality also can be perceived as a gateway to access the past. The challenge consists in conceiving them as artifacts, and to question about the concrete conditions of their fabrication. For instance, a typewritten text allows considerations about the type of paper employed (copying paper or silk), the technique employed (portable or tabletop typewriter, mechanical or electrical), aspect (original or copy, and in this case, use of carbon copy or photocopy). Each of these questions refers to a set of learnings about the technologies of writing in a historical perspective, and about bodily practices induced by such materials.

If the typewriter is a tabletop electric typewriter, writing can only take place in a specific space, either an office or a working room; for the portable mechanical typewriter, spaces can be improvised and it is up to the person to create the adequate conditions for the act of writing. It also refers to the formality of writing practices, consecrated in social uses, such as forms of treatment and narrative genres, amongst others. All these aspects allow one to carry out a "journey" in time, and to recognize past ways for the construction of knowledge.

Operating with the materiality of documents brings, therefore, the opportunity of exploring human experience in different temporalities. To stay on the same example, the contrast between the writing objects used in the past to create the document opens a pathway to reflection about the historical changes and their social, cultural, economic and bodily effects. The possibilities of reproducing a text with a carbon copy in a mechanical device were limited. Consequently, making several copies of a text often meant retyping it many times. Similarly, altering a typed text used to mean making side notes, adjusting handwritten text or even the actual activity of cutting and pasting a new piece onto the paper. 
We live in a world of artifacts, constructed as extensions of our body, and situated in an environment that is, at one and the same time, condition of exhaustion and of overcoming human experience (Warnier, 1999). To recover the sensory and concrete dimension of life allows to look at subjects in the past and consider their trajectories as resulting from the negotiation between impulse and constraint. It reweaves the notion of homo faber, no longer conceived just as someone who can control destiny through the use of tools, but as someone who is also molded by the materiality in which they live.

Still, exploring materiality is not restricted to this approach. Another dimension can also be accessed when the investigation falls upon the conditions of survival of documents through time, or upon the reasons for the disappearance of vestiges of the past. The value of proof is in many cases what leads to the preservation of the document. This is valid both for institutional archives and for personal archives. Student records, school records, employment documentation are kept more frequently than students' essays and class plans in school archives. Birth or marriage certificates, receipts and other certificates remain, whereas other testimonies of daily life disappear from personal archives. Sentimental value is another distinctive factor for preservation. Photographs of school events or of family scenes, personal correspondence and journals are objects we often found in archives.

Beyond these social and cultural conditionings, it is worth taking into account other personal aspects (such as changes of address, illnesses and family events, births, weddings, separations) and historical aspects (such as natural disasters and political events, wars and revolutions), amongst others, that may damage the documents, the collections and even the public and private archival institutions. These are material conditions of life that are reflected also in actions of documental preservation.

One final concern has to do with the means of preservation. The very space of the archive can be problematized in the conditions of keeping that it displays. The exercise of sanitizing, the objects employed to prevent attack to the material support, the recourse to neutral papers to avoid or retard the degradation process, the packaging in boxes, the control of humidity, temperature and lighting: these are all issues directly associated to materiality, whose care and observation are responsible for the long life of a document or collection. In other words without these specials conditions of preservation the survival of these vestiges of the past may not occur.

What has been kept? Why? In which conditions? How has it survived the oblivion? What place does it take in the archive? When did it arrive at an institutional archive? By which means? When was it processed by the archivists? What does the materiality tell us about it? And, on the contrary, what might have been kept? What is missing? Which gaps are there in the collections? Which narratives have archivists and collectors told when organizing the documents? These are some questions that can be asked to make the encounter between the historian of education and the document richer in meanings and to provoke new interpretations about the former times. All of them concern to the inability to keep everything and, for this reason, they underline the contingencies of the acts of archiving, as well as their interferences, in the efforts to fabricating meanings to yesterday.

After all, it is from a present, which can be situated in the past, that documents are collected and archives are constituted, sometimes organized and preserved. The act of keeping is guided by a wish of memory expressed in the meaning attributed to the documents preserved, which are sources of one or various identities attributed to 
the past. However the survival of a document is not only the result of fight against oblivion and time, it is also an effect of fortune.

\section{Final Considerations}

If the past is a constant reconstruction in view of the appeals of the present, that implies the existence of several layers of temporality in what we consider to be the former times. The singular (past) should not preclude the investigation of the multiplicity of moments that do not accumulate successively, as if in a logical chain. On the contrary, they intermingle, they reconvene and change not just with the passing of the years, but with new commitments made in the present time.

It is worth mentioning that the debates about the fabricating meanings for the past are not a novelty in the historiographical field. As a counterpoint to all sort of revisionisms that have been haunting the world nowadays - and so that we shall never forget the atrocities that have been committed -, we chose to recall Marc Bloch (2001).

Arrested and tortured by Gestapo $^{3}$, the historian left an unfinished book about some aspects of the historian's craft. Among them, he defended the idea that history should be understood as the science that is interested in the actions of subjects in time. In other words, much more than efforts to study the past, the attention should be directed to the actions of the subjects at different intervals of duration. To that extent, for the author, the historian, like the "ogre of legend", should pay attention to the "human flesh", sniffing it in the varied temporalities (short, long, simultaneous, competing) that interfered (and, a certain way, remain interfering) in the relationships, permanences and transformations between the past and the present (Bloch, 2001, p. 54). This reframing in the ways of looking at temporalities is not a smooth movement. After all, he wondered: "what is in effect the present? In the infinite of duration, a minute point that runs away incessantly; an instant that is dead as soon as it is born" (Bloch, 2001, p. 60).

As interpreters of the past and of the present, archivists and historians of education produce narratives of the yesterday that tend to encapsulate it an interpretive plot. They are guided by the conditions of their disciplines and in their work archivists and historians of education reveal the urgencies of their time, as claims Michel de Certeau (1988). Therefore, the question always opens that rises different answers, is: in which conditions have the interpretations emerged? Perhaps that is the surest lighthouse to guide us when immersing ourselves into archives and historiographies.

\section{References}

Bloch, M. (2001). Apologia à história ou o ofício do historiador. Rio de Janeiro: Jorge Zahar.

Burke, P. (2001). New Perspectives on Historical Writing. Cambridge: Polity Press. 
Carvalho, M.; Vidal, D. (2001). Mulheres e Magistério Primário: tensões, ambiguidades e deslocamentos. In: M.L. Hilsdorf, D. Vidal (eds.). Brasil 500 anos: tópicas em História da Educação (pp. 205-224). São Paulo: EDUSP.

Castells, M. (2006). A Sociedade em Rede: do conhecimento à política. In: G.Cardoso, M.Castells (eds.). A Sociedade em Rede: do conhecimento à acção política (pp. 17-30). Belém (Portugal): Imprensa Nacional.

Catani, D. B., Faria Filho, L. M. (2002). Um lugar de produção e a produção de um lugar: a história e a historiografia divulgadas no GT História da Educação da ANPEd (1985-2000). Revista Brasileira de Educação, 19: 113-128.

Chalhoub, S. (1990). Visões da liberdade: uma história das últimas décadas da escravidão na Corte. São Paulo: Companhia das Letras.

Coleção de leis do Império do Brasil. In <http://www.planalto.gov.br/ccivil_03/constituicao/constitui\%C3\%A7ao24.htm>. (ultima consultazione: 07/02/2020).

Darnton, R (1999). The Great Cat Massacre and Other Episodes in French Cultural History. New York: Basic Books.

De Certeau, M. (1988). The Writing of History. New York: Columbia University Press.

Farge, A. (1989). Le gout de l'archive. Paris: Ed. Seuil.

Foucault, M. (1975). Vigiar e punir: o nascimento da prisão. Petrópolis: Vozes.

Foucault, M. 2012). Du gouvernement des vivants. Paris: EHESS.

Genovese, E.; Roll, J. Roll: The World the Slaves Made. New York, Pantheon Books.

Le Goff, J. (1984). "Memória". In: Enciclopédia Einaudi, vol. 1, História-Memória. Lisboa: Imprensa Nacional-Casa da Moeda, p. 11-50.

Moraes, F. (2015). O processo de escolarização pública na Vila de Cotia no contexto cultural caipira (1870-1885). Dissertação de mestrado - Faculdade de Educação, Universidade de São Paulo, São Paulo.

Nora, P. (1993). "Entre memória e história: a problemática dos lugares". Projeto História. São Paulo (10): 7-28, dez.

Pimenta, R. (2017). Nosso futuro em um post. Cultura da velocidade, big data e o novo desafio do "peixe" para os historiadores da era digital. Revista Transversos, 11:9-22.

Schueler, A. (2002). Formas e Culturas Escolares na Cidade do Rio de Janeiro: representações, experiências e profissionalização docente em escolas públicas primárias (1870-1890). Tese (Doutorado), UFF, Niterói.

Schwarcz, L. (1987). Retrato em branco e negro: jornais, escravos e cidadãos em São Paulo no fim do século XIX. São Paulo: Companhia das Letras.

Scott, R. (1985). Slave Emancipation In Cuba: The Transition to Free Labor, 18601899. University of Pittsburgh Press. 
Silva, A. M. P. da. (2000). Aprender com perfeição e sem coação: uma escola para meninos pretos e pardos na Corte. Brasília: Editora Plano.

Silva, A. M. P. da. (2007). Processos de construção das práticas de escolarização em Pernambuco, em fins do século XVIII e primeira metade do século XIX. Recife: Editora Universitária UFPE.

Slenes, R (1999). Na Senzala uma Flor: Esperanças na Formação da Família Escrava. Brasil Sudeste, século XIX. Rio de Janeiro: Nova Fronteira.

Vidal, D. (2008). "Mapas de frequência a escolas de primeiras letras: fontes para uma história da escolarização e do trabalho docente em São Paulo na primeira metade do século XIX." Revista Brasileira de História da Educação, Maringá, v. 17, p.41-67.

Warnier, J. (1999). Construire la culture matérielle. L'homme qui pensait avec ses doigts. Paris: Presses Universitaires de France.

\section{Nota}

1 This reflection is part of the studies conducted within the Thematic Project "Knowledges and practices at the borders: for a transnational history of education (1810-...", process FAPESP No. 2018/26699-4, and within the scope of a Research Productivity Scholarship granted by CNPq.

${ }^{2}$ This article dialogues with the studies carried out within the scope of the Young Scientist of Our State Scholarship, process FAPERJ, No. E-26/203.254/2016.

${ }_{3}^{3}$ Marc Bloch was shot dead by Gestapo on 16 July 1944. 